\title{
NEW CONSTRAINTS FOR THE ALPINE HP METAMORPHISM OF THE IOS BASEMENT, CYCLADES, GREECE

\author{
M. PERRAKI ${ }^{1} \&$ E. MPOSKOS ${ }^{1}$
}

\begin{abstract}
The pre-Alpine basement of the Ios Island involves large Variscan granitoid bodies intruded into metasediments that had already been metamorphosed under upper amphibolite facies conditions, as it is indicated by residual migmatitic textures and deformed muscovite pegmatites. The Alpine HP-metamorphism, documented on various cycladic islands, has, also, affected the basement rocks of Ios. Pressures of ' $25 \mathrm{Kbar}$ and temperatures of $540{ }^{\circ} \mathrm{C}$, are estimated for the Alpine HP event, applying the chloritoid-chlorite and garnetclinopyroxene geothermometers, and the garnet-phengite-omphacite and garnet-rutile-quartz-sphene-clinozoisite geobarometers. Garnet-hornblende geothermometry yielded temperatures of ${ }^{\prime} 520{ }^{\circ} \mathrm{C}$ and garnet-chlorite geothermobarometry yielded temperatures of $450{ }^{\circ} \mathrm{C}$ at $15 \mathrm{Kbar}$. This suggests that, at least the first stages of decompression were accompanied by cooling, indicating a rapid exhumation, related to tectonic processes.
\end{abstract}

KEY WORDS: Ios island, Cyclades, pre-Alpine basement, Alpine HP metamorphism

\section{INTRODUCTION}

Ios Island belongs to the Cycladic crystalline complex of the southern Aegean representing Godwanian fragments, amalgamated to the Eurasian plate during Tertiary (Papanikolaou, 1996).

The Cycladic crystalline complex consists of three major tectonic units. The lower unit comprises pre-Alpine crystalline rocks of the Apulia basement, being widespread in the islands of Ios, Paros, Antiparos, Delos, Naxos and Sikinos. The intermediate unit comprises metasediments and metavolcanic rocks of Mesozoic protoliths. The basement and the Mesozoic cover underwent an Upper Cretaceous-Eocene high-pressure metamorphism (Altherr et al., 1982; Andriessen et al., 1987; Broecker \& Enders, 1999). In Oligocene-Miocene, the rocks were largely overprinted by a medium pressure metamorphism and intruded by granitoid magmas. The upper unit consists of remnants of an ophiolite nappe (on Paros) and slices of Permian and Triassic metasediments metamorphosed under very low grade conditions (e.g. on Myconos, Naxos, Thymeana; Durr et al., 1978) as well as LP/HT crystalline rocks (Nikouria, Donnousa, Ikaria, Anafi) interpreted by Langosh et al (2000 and references therein) to be of Late Cretaceous age.

\section{GEOLOGICAL SETTING}

The three tectonometamorphic units building up the cycladic crystalline complex are, also, present in the island of Ios (Fig. 1): the lower one is the pre-Alpine basement, composed of garnet-mica schists and para- and orthogneisses. It is tectonically overlain by the Southern Cyclades Unit, a sequence of thick carbonate unit containing lenses of metabauxites with intervening schists and mafic lenses (Van der Maar, 1981). The upper tectonic unit, composed of crystalline limestones of Permian age, phyllites and metabasites metamorphosed at very low-grade conditions, similar to the Dryos Unit of Paros (Papanikolaou, 1996), was recognized for the first time in Ios. It occurs, only, in the small Koubara peninsula at the western part of Ios. It overlies marbles and metabasites of the Southern Cyclades Unit through a low angle normal fault.

The garnet-mica schists of the pre-Alpine basement are intensely deformed. They, still, preserve earlier migmatitic textures, which are more obvious in less deformed domains, indicating that the basement of Ios had suffered a high temperature metamorphism (M0). Muscovite pegmatites probably formed during this metamorphic event. The orthogneisses occupy the most of the central and the southern part of the island. They appear, predominantly, as augengneisses. The metagranites, still preserving magmatic textures, occur as distinct bodies within the garnet-mica schists as well as within the augengneisses. Orthogneisses and metagranites have a Variscan

1. National Technical University of Athens, Section of Geological Sciences, Heroon Politechniou 9, GR-15780, Zografou (Athens), GREECE, e.mail: mposkos@metal.ntua.gr 


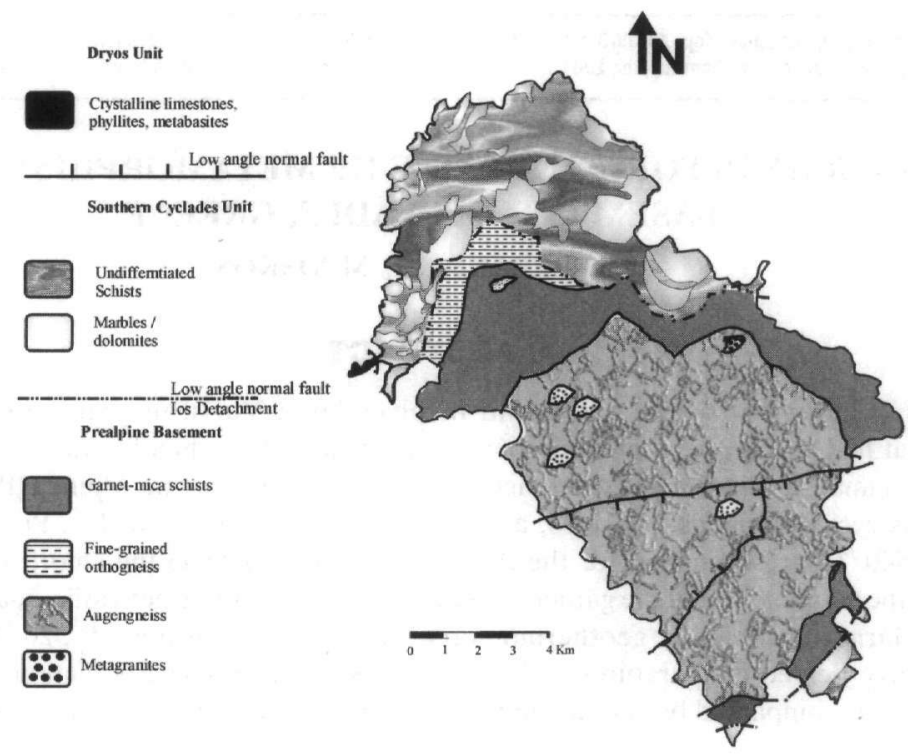

Figure 1: A simplified geological map of Ios, Cyclades, Greece (based on mapping by Van der Maar, 1981 including modifications by Vandenberg \& Lister, 1996 and our field observations)

intrusion age ('300 Ma) dated by $\mathrm{Pb}-\mathrm{Pb}$ method on magmatic zircons (Engel \& Reischmann, 1998) and $\mathrm{Rb}-\mathrm{Sr}$ method on magmatic muscovites of the metagranites (Henjes-Kunst \& Kreuzer, 1982). The pre-Alpine basement and the Southern Cyclades Unit underwent Alpine HP metamorphism during Upper Cretaceous-Eocene (M1) indicated by the presence of blueschists and eclogites, followed by a Barrovian metamorphic event (M2) in Oligocene-Miocene (Henjes-Kunst \& Kreuzer, 1982; Van der Maar, 1981). In this paper, new insights are given for the pre-Alpine and the Alpine metamorphism of the Ios basement, based on new petrological data and thermodynamic calculations on analyzed mineral phases.

\section{PETROGRAPHY AND MINERAL CHEMISTRY OF THE PRE-ALPINE LITHOLOGIES}

The pre-Alpine basement comprises garnet-mica schists cut by deformed metapegmatites, metagranitic rocks of different deformation grade (metagranites, mylonitic and ultramylonitic orthogneisses) and lensoidal metabasic rocks. Mineral compositions presented in this work are obtained by electron microprobe analyses using the JEOL 733 Superprobe of IGME.

\section{Garnet-mica schists}

The garnet-mica schists occur in a zone around the augengneiss as well as within it.

Despite the penetrative Alpine deformation residual migmatitic textures such as alternating leucocratic quartzfeldspar-rich and melanocratic garnet-mica rich layers and dark, lensoidal, biotite-rich domains (melanosome) are still preserved imprinting an earlier HT metamorphism. Intensely deformed pegmatitic dykes cut the garnetmica schists (Fig. 2).

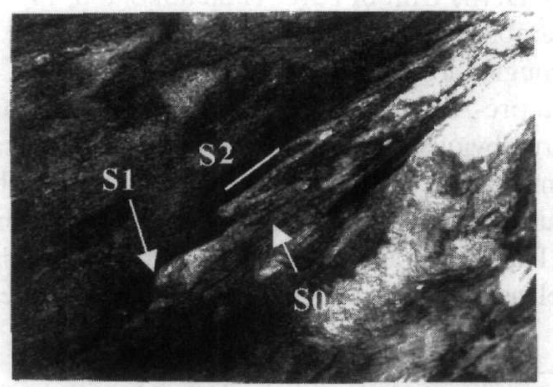

Figure 2: Deformed pegmatites in garnet-mica schists. 
The garnet-mica schists are represented by the mineral assemblage Grt-Bi-Ab-Phen/Ms-Chl-Qtz$\pm \mathrm{Pr} \pm \mathrm{Gln} \pm \mathrm{Cld} \pm \mathrm{Omp} \pm \mathrm{Hbl} \pm \mathrm{Ap} \pm \mathrm{Ttn}$ (Abbreviations after Bucher \& Frey, 1994).

Two generations of garnet can be distinguished. The first generation (Grt1), associated with biotite (Bi1), forms porphyroblasts with corroded edges containing numerous quartz inclusions imprinting older folds isolated from the surrounding schistosity (Plate I,A). It is an almandine rich garnet, low in grossular component having the composition $\mathrm{Grs}_{3-9} \mathrm{Alm}_{68-75} \operatorname{Prp}_{9-17} \mathrm{Sps}_{2-18}$. Grt1 is considered to have formed during the pre-Alpine high temperature metamorphism. The second garnet generation (Grt2) forms fine grain aggregates (Plate I,B). It is an almandine rich garnet with a composition Grs ${ }_{14-27 \%} \mathrm{Alm}_{55-71 \%} \mathrm{Py}_{1.9-13 \%} \mathrm{Sps}_{0.9-21.37 \%}$. It shows a growth-zoning pattern with increasing $\mathrm{FeO}$ and $\mathrm{MgO}$ content and decreasing $\mathrm{MnO}$ content towards the rim (Table 1), indicating prograde metamorphism. The grossular-component is five times higher than that of the Grt1 (Table 1). It is considered to have formed during the Alpine HP metamorphic event replacing primary biotite (Bi1)(Plate I,C) and plagioclase. In chloritoid bearing metapelites, Grt2 is formed replacing chlorite and chloritoid according to the reaction $\mathrm{Cld}+\mathrm{Chl}+\mathrm{Qtz}=\mathrm{Grt}+\mathrm{W}$.

Omphacite has a jadeite content of $25 \%$ and along with garnet and phengite, replace former biotite (Plate I,D) and plagioclase.

Primary K-white micas (Ms1) are prekinematic muscovites with a negligible celadonitic component and a relatively high Ti-content (Table 1, Fig. 4). Phengitic muscovites (Ms2) formed during the Alpine HP-metamorphic event are characterized by a high Si-content ranging from 6.4 to 6.9 atoms per formula unit (p.f.u.) and low titanium content $\left(\mathrm{TiO}_{2}=0-0.2 \%\right.$, Table 1). Chlorite is intergrown with white mica oriented along the dominant foliation. It is replaced by biotite ( $\mathrm{Bi} 2)$ with lower $\mathrm{TiO}_{2}$ content in relation to the pre-Alpine one (Bi1). A second chlorite generation is formed replacing garnet, during the greenschist facies overprinting (M2). Albite porphyroblasts, formed probably during M2, are rich in quartz, clinozoisite, phengite, garnet and rarely glaucophane inclusions.

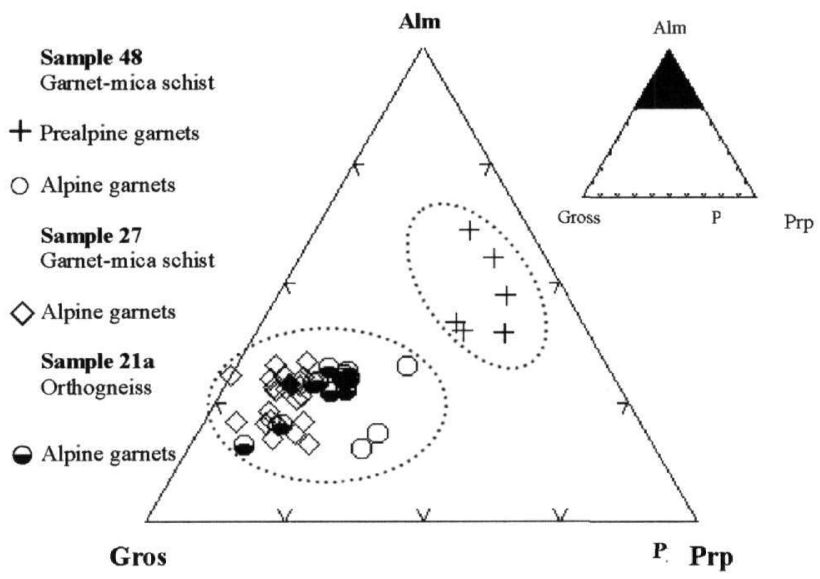

Figure 3: Ternary diagram (Almandine-Grossular-Pyrope) showing the compositional variation of garnets from garnet-mica schists (Samples 48, 27) and orthogneisses (Sample 21). In sample 48 the two generations of garnet, distinguished texturally, show, also, remarkable differences in their chemical composition.

\section{Metapegmatites}

Pegmatitic dykes cut the migmatitized garnet-mica schists. Pegmatites are isoclinally folded showing penetrative deformation almost the same with that of the surrounding garnet-mica schists (Fig. 2). They consist of muscovite, phengite, quartz, K-feldspar (microcline), albite as well as biotite in minor content. As in the garnetmica schist, two generations of K-white mica are present in the metapegmatites. Large prekinematic, almost, pure muscovite up to $5 \mathrm{~cm}$ in size, with a low iron and magnesium content and phengitic muscovite rich in iron and magnesium ( $\mathrm{FeO} 4.6-5.5 \%, \mathrm{MgO} 2.6-3 \%$ ) with a Si content ranging from 6.5-6.7 atoms p.f.u. (Fig. 4). Magmatic muscovite is replaced by phengite indicating the effect of the HP metamorphic event. 


\section{Metagranites-orthogneisses-augengneisses}

Metamorphosed magmatic rocks of granitic composition are widespread in the Ios basement. They mainly consist of Kfs-Pl-Qtz-Phen/Ms-Bi-Grt-Czo-Chl-Cld-Ttn-Rt. They show remarkable differences on the degree of deformation. Domains where the rock is weakly deformed behaved as megaboudins during the Alpine deformation, domains where the rock is mylonitic are characterized as S- tectonite (orthogneiss) along shear zones and domains where the rock is ultramylonitic are characterized as LS-tectonite and L-tectonite (augengneiss and ultramylonite, respectively). The augengneisses dominate and form the domal geomorphology.

Table 1: Representative mineral compositions from garnet-mica schists

\begin{tabular}{|c|c|c|c|c|c|c|c|c|c|c|c|}
\hline & Grt1 & Grt2C & Grt2r & Ms1 & Ms2 & Bi1 & Chl & Cld & Prg & Omph & Amph \\
\hline $\mathrm{SiO}_{2}$ & 36.76 & 36.50 & 38.01 & 44.9 & 51.41 & 35.44 & 26.16 & 24.15 & 44.25 & 49.81 & 47.72 \\
\hline $\mathrm{TiO}_{2}$ & 0.00 & 0.17 & 0.81 & 1.11 & 0.37 & 2.60 & 0.09 & - & 0.18 & 0.30 & 0.33 \\
\hline $\mathrm{Al}_{2} \mathrm{O}_{3}$ & 20.81 & 20.90 & 20.91 & 36.11 & 26.99 & 16.61 & 19.91 & 41.10 & 40.89 & 13.33 & 10.71 \\
\hline $\mathrm{FeO}$ & 30.39 & 25.42 & 29.53 & 0.89 & 1.91 & 22.47 & 22.53 & 21.50 & 0.18 & 14.17 & 18.34 \\
\hline $\mathrm{MnO}$ & 7.88 & 9.63 & 0.51 & - & - & - & - & 0.10 & - & - & 0.04 \\
\hline $\mathrm{MgO}$ & 2.25 & 0.73 & 1.41 & 0.71 & 3.51 & 8.01 & 17.39 & 4.60 & - & 10.83 & 8.88 \\
\hline $\mathrm{CaO}$ & 1.21 & 7.15 & 9.19 & - & - & 0.15 & - & - & 0.33 & 7.87 & 8.59 \\
\hline $\mathrm{Na}_{2} \mathrm{O}$ & - & - & - & - & 0.75 & - & - & - & 8.17 & 2.93 & 1.64 \\
\hline $\mathrm{K}_{2} \mathrm{O}$ & - & - & - & 10.71 & 10.44 & 9.97 & - & - & 0.85 & 0.41 & 0.83 \\
\hline $\mathrm{Total}$ & 99.30 & 100.50 & 100.37 & 94.43 & 95.40 & 95.25 & 86.08 & 91.45 & 94.85 & 99.68 & 97.09 \\
\hline $\mathrm{Cations} /$ & 24 & 24 & 24 & 22 & 22 & 22 & 28 & 24 & 22 & 6 & 23 \\
\hline $\mathrm{O}$ atoms & & & & & & & & & & \\
\hline $\mathrm{Si}$ & 5.99 & 5.90 & 6.03 & 6.02 & 6.84 & 5.51 & 5.52 & 3.97 & 5.73 & 1.83 & 7.09 \\
\hline $\mathrm{Ti}$ & - & 0.02 & 0.1 & 0.11 & 0.04 & 0.30 & 0.10 & - & - & 0.01 & 0.04 \\
\hline $\mathrm{Al}$ & 4.00 & 3.99 & 3.91 & 5.71 & 4.23 & 3.04 & 4.96 & 7.96 & 6.24 & 0.58 & 1.87 \\
\hline $\mathrm{Fe}$ & 4.15 & 3.43 & 3.92 & 0.09 & 0.21 & 2.92 & 3.98 & 2.95 & 0.01 & 0.44 & 2.28 \\
\hline $\mathrm{Mn}$ & 1.08 & 1.32 & 0.06 & 0.00 & - & - & - & 1.12 & - & - & 0.01 \\
\hline $\mathrm{Mg}$ & 0.55 & 0.18 & 0.33 & 0.14 & 0.70 & 1.85 & 5.48 & 1.12 & - & 0.59 & 1.97 \\
\hline $\mathrm{Ca}$ & 0.21 & 1.24 & 1.56 & - & - & 0.02 & - & - & 0.04 & 0.31 & 1.37 \\
\hline $\mathrm{Na}$ & - & - & - & - & 0.20 & - & - & - & 2.05 & 0.21 & 0.47 \\
\hline $\mathrm{K}$ & - & - & - & 1.83 & 1.77 & 1.97 & - & - & 0.14 & 0.02 & 0.16 \\
\hline
\end{tabular}

Table 2: Representative mineral compositions from orthogneisses and metagranites

\begin{tabular}{|l|c|c|c|c|c|c|c|c|c|c|c|}
\hline & \multicolumn{3}{|c|}{ Metagranite } & \multicolumn{9}{c|}{ Orthogneisses } \\
\hline & Bi1 & Ms1 & Ms2 & Ms1 & $\begin{array}{c}\text { Ms2 } \\
\text { core }\end{array}$ & $\begin{array}{c}\text { Ms2 } \\
\text { rim }\end{array}$ & Bi1 & Bi2 & Cld & Rt & Sph \\
\hline $\mathrm{SiO}_{2}$ & 33.49 & 45.14 & 49.96 & 45.19 & 49.32 & 47.73 & 35.52 & 34.65 & 24.92 & 0.63 & 30.55 \\
\hline $\mathrm{TiO}_{2}$ & 3.08 & 1.09 & 0.78 & 1.10 & 0.59 & 0.62 & 2.61 & 1.60 & - & 96.88 & 37.91 \\
\hline $\mathrm{Al}_{2} \mathrm{O}_{3}$ & 17.29 & 34.25 & 22.61 & 34.28 & 28.65 & 30.79 & 16.46 & 17.00 & 40.46 & 0.26 & 2.33 \\
\hline $\mathrm{FeO}$ & 21.39 & 1.81 & 7.21 & 1.81 & 1.87 & 1.81 & 22.52 & 26.45 & 25.74 & 1.49 & 0.42 \\
\hline $\mathrm{MnO}$ & 0.37 & - & - & 0.00 & - & - & - & 0.35 & 0.27 & - & 0.11 \\
\hline $\mathrm{MgO}$ & 8.77 & 1.04 & 3.62 & 1.04 & 3.00 & 3.23 & 8.03 & 5.40 & 2.90 & - & - \\
\hline $\mathrm{CaO}$ & 0.39 & - & 0.16 & 0.00 & - & - & 0.15 & 0.20 & - & 0.33 & 28.84 \\
\hline $\mathrm{Na}_{2} \mathrm{O}$ & - & 0.39 & - & 0.39 & 0.64 & 0.57 & - & 0.10 & - & - & - \\
\hline $\mathrm{K}_{2} \mathrm{O}$ & 10.00 & 11.55 & 10.43 & 11.56 & 10.52 & 10.88 & 9.99 & 8.50 & - & - & - \\
\hline $\mathrm{Total}$ & 95.45 & 95.30 & 94.80 & 95.40 & 94.60 & 94.75 & 95.46 & 94.25 & 94.29 & 99.60 & 100.19 \\
\hline $\mathrm{Cations}$ & 22 & 22 & 22 & 22 & 22 & 22 & 22 & 22 & 24 & 2 & 5 \\
$\mathrm{O}$ atoms & & & & & & & & & & & \\
\hline $\mathrm{Si}$ & 5.24 & 6.08 & 6.89 & 6.08 & 6.63 & 6.42 & 5.51 & 5.52 & 4.05 & 0.01 & 0.99 \\
\hline $\mathrm{Ti}$ & 0.36 & 0.11 & 0.08 & 0.11 & 0.06 & 0.06 & 0.30 & 0.19 & - & 0.98 & 0.92 \\
\hline $\mathrm{Al}$ & 5.19 & 5.43 & 3.68 & 5.43 & 4.54 & 4.88 & 3.04 & 3.19 & 7.77 & 0.01 & 0.09 \\
\hline $\mathrm{Fe}$ & 2.79 & 0.20 & 0.20 & 0.20 & 0.21 & 0.20 & 2.92 & 3.52 & 3.50 & 0.02 & 0.01 \\
\hline $\mathrm{Mn}$ & 0.05 & - & - & 0.00 & - & - & - & 0.05 & 0.03 & - & 0.01 \\
\hline $\mathrm{Mg}$ & 2.04 & 0.21 & 0.74 & 0.21 & 0.60 & 0.46 & 1.85 & 1.28 & 0.70 & - & - \\
\hline $\mathrm{Ca}$ & 0.06 & - & 0.02 & 0.00 & - & - & 0.02 & 0.03 & - & 0.01 & 1.01 \\
\hline $\mathrm{Na}$ & - & 0.10 & - & 0.10 & 0.17 & 0.14 & - & 0.03 & - & - & - \\
\hline $\mathrm{K}$ & 2.00 & 1.99 & 1.83 & 1.98 & 1.81 & 1.87 & 1.98 & 1.72 & - & - & - \\
\hline
\end{tabular}

Large relict flakes of prekinematic magmatic muscovite are associated with brown biotite. The Si-content ranges from 6.00 to 6.15 atoms p.f.u. They are relatively rich in titanium with a $\mathrm{TiO}_{2}$-content ranging from 0.7 to $1.37 \%$ (Table 2). A second generation of white K-micas is intergrown with garnet and rutile needles in the form of sagenite replacing former biotite. It is phengitic mica with Si-content in the range of 6.7-6.9 atoms p.f.u. (Fig. 
4) and with a Ti-content significantly lower than that of the magmatic one (Table 2). Chemical zoning with metamorphic phengitic rim and magmatic muscovite core (Plate I,E) isalso observed in large mica flakes. In shear zones the Si content of the phengitic rim is less than that of the less deformed domains (Fig. 4) indicating that mylonitization along the shear zones took place with pressure decrease during exhumation.
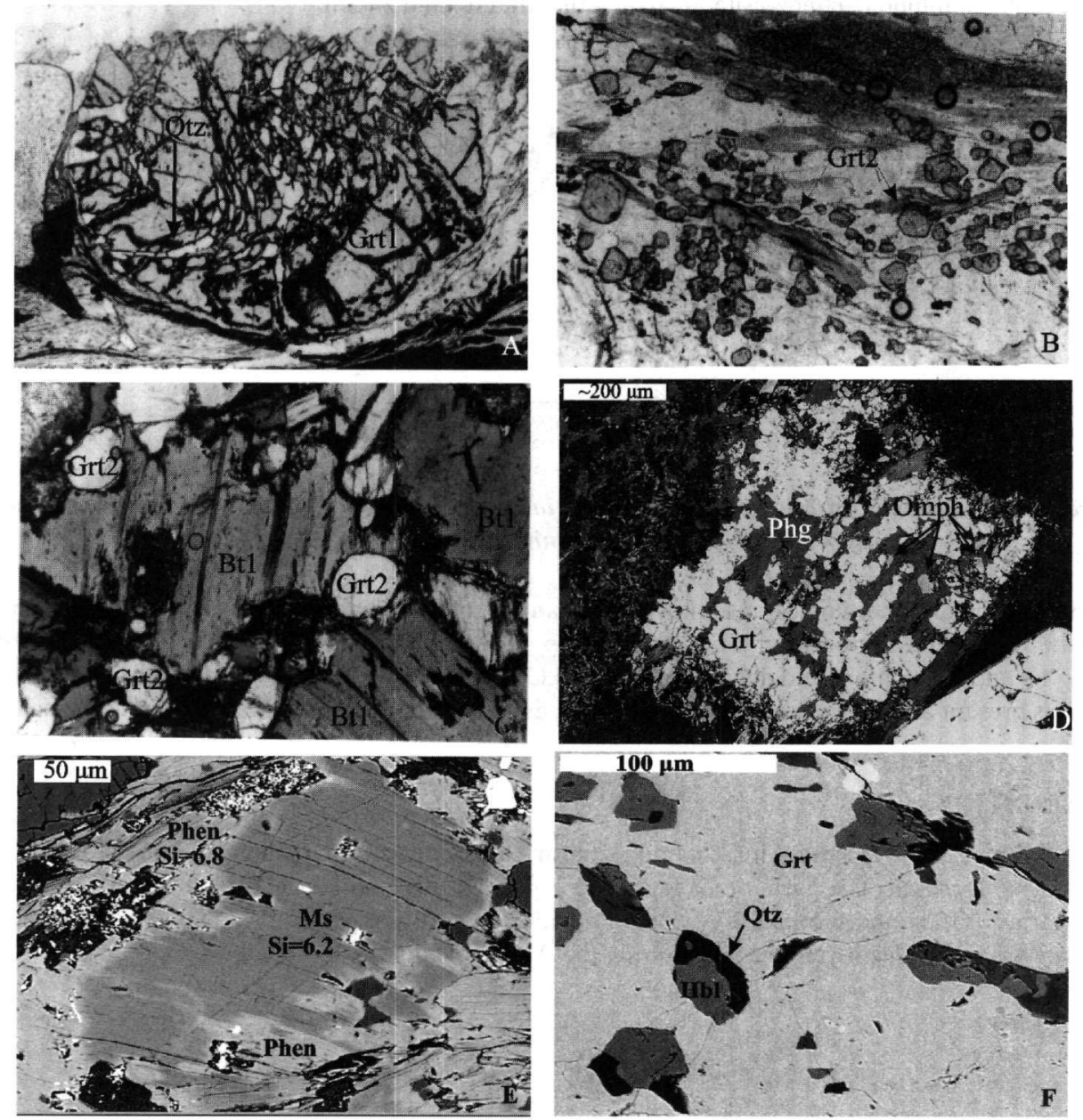

Plate I:

A.Isolated folded quartz inclusions within a prealpine garnet (garnet growth syntectonically with the SI schistosity defined by the quartz inclusions, // Nicols, length of photograph $2.4 \mathrm{~mm}$ ).

B.Fine grain garnet aggregates grown during the alpine metamorphic event (garnet-mica schist, // Nicols, length of photograph $2.4 \mathrm{~mm}$ ).

C.Idiomorphic garnets grown during the alpine metamorphic event at the expense of primary biotite(garnet-mica schist, // Nicols, length of photograph $6 \mathrm{~mm}$ ).

D.Backscattered electron image of garnet, phengite and omphacite pseudomorphosing prealpine biotite (garnetmica schist).

E.Backscattered electron image of magmatic muscovite replaced at its rims by metamorphic high-Si phengite (orthogneiss from a shear zone).

F.Backscattered electron image of garnet containing inclusions of hornblende and quartz (garnet-mica schist). 
Reddish brown biotite occurs as relict crystals and is partly replaced by phengite. K-feldspar is microcline and occurs as the predominant phase. In the augengneisses it forms characteristic $\sigma$ to $\delta$ porphyroclasts surrounded by the dominant foliation as a result of simple shear, showing South-directed sense of shear. Albite $(\mathrm{An}<5 \%)$ forms water clear, commonly untwinned elongated porhyroblasts, rich in inclusions of garnet, phengite, paragonite, blue amphibole, clinozoisite, quartz, rutile, titanite and zircon.

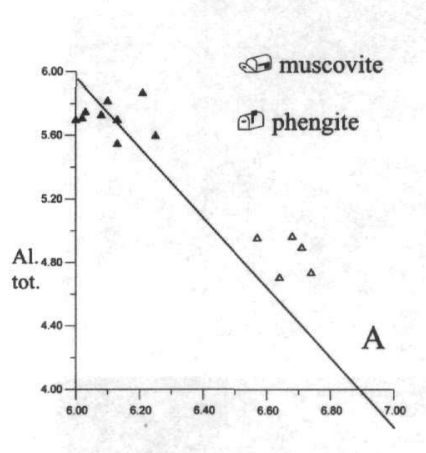

$\mathrm{Si}$

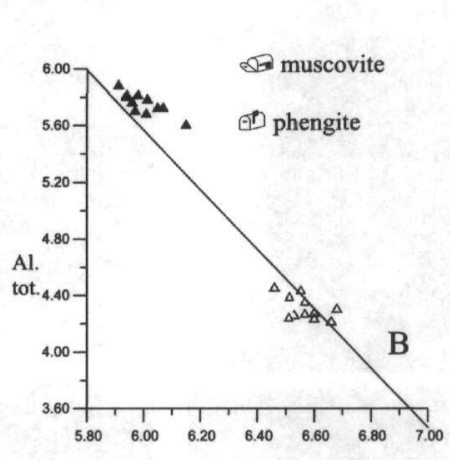

Si

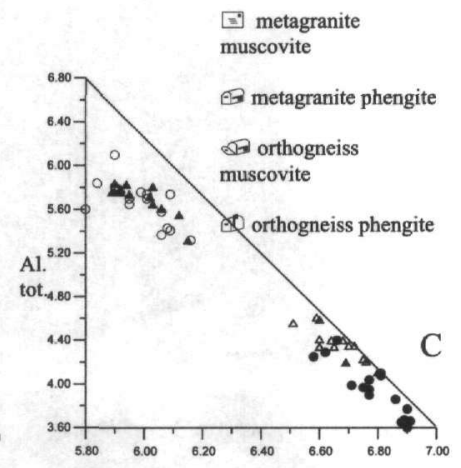

$\mathrm{Si}$

Figure 4: Compositional variation of $K$-white micas in terms of Altot vs. Si from a garnet-mica schist (A), a metapegmatite $(B)$, a metagranite $(C)$ and an orthogneisss $(C)$.

Garnet is a main mineralogical constituent. It is an almandine rich garnet with a relatively high grossular component, having the composition $\mathrm{Grs}_{18-26} \mathrm{Alm}_{58-71} \operatorname{Prp}_{6-12} \mathrm{Sps}_{0.5-55^{\circ}}$ Garnet shows a "growth zoning" pattern with increasing Fe and $\mathrm{Mg}$ content and decreasing $\mathrm{Mn}$ and $\mathrm{Ca}$ content from the core to the rim (Table 2).

Rutile is present as inclusions in garnet and albite, as well as in the matrix. Matrix rutile is partially replaced by titanite.

\section{P-T CONDITIONS}

P-T conditions of the HT pre-Alpine metamorphism cannot be well constrained due to the lack of appropriate mineral parageneses. The garnet-biotite Fe-Mg exchange thermometer (Ferry \& Spear, 1978) applied to adjacent garnet (Grt1) and biotite (Bi1) yielded a wide range of temperatures $\left(600-780{ }^{\circ} \mathrm{C}\right)$, indicating that equilibrium was partly destroyed probably during the Alpine events.

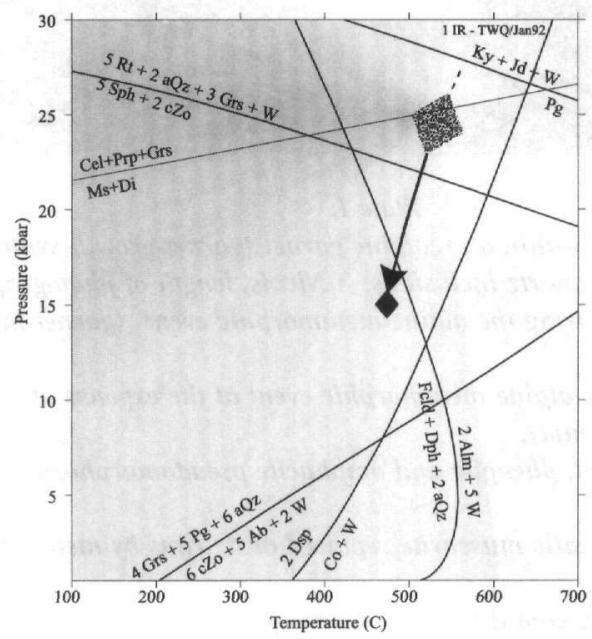

Figure 5: P-T diagram depicting reaction curves determined with the TWQ software program, for the Alpine HP metamorphic event. Real mineral compositions from garnet-mica schists and orthogneisses of Ios basement were used. Large diamond shows the approximate peak metamorphic conditions. Arrow shows the first stages of the decompression path. 
P-T conditions of the Alpine HP metamorphism are well constrained using the empirical chloritoid-chlorite thermometer (Vidal et al. 1999), the garnet-pyroxene geothermometer (Powell, 1985), the garnet-chlorite geothermobarometer (Grambling 1990), the garnet-phengite-omphacite geobarometer (Waters \& Martin, 1993), the garnet-hornblende geothermometer (Graham \& Powell, 1984) and the equilibrium reaction curves $\mathrm{Rt}+\mathrm{Qtz}+\mathrm{Grt}+\mathrm{H}_{2} \mathrm{O}=\mathrm{Sph}+\mathrm{Czo}$ (Manning \& Bohlen, 1991), $\mathrm{Cld}+\mathrm{Chl}+\mathrm{Qz}=\mathrm{Grt}+\mathrm{H}_{2} \mathrm{O}$ and $\mathrm{Dsp}=\mathrm{Co}+\mathrm{H}_{2} \mathrm{O}$, calculated with the TWQ software program v. 1.02 (Berman, 1991), using the analyzed mineral phases. Ideal solid solution models were used for calculating the activity of the mineral phases, except for garnet, which activity was estimated, applying Berman's solid solution model (1990). The calculated reactions are presented in Fig. 5. Mineral assemblages Cld-Chl-Grt, with chloritoid and chlorite as inclusions in garnet, present in the mica schists, indicates that temperatures exceeded those of the reaction curve Chl+ $\mathrm{Ctd}+\mathrm{Qtz}=\mathrm{Grt}+\mathrm{H}_{2} \mathrm{O}$ (Fig. 5). The chloritoid-chlorite geothermometer, applied on coexistent chloritoid-chlorite inclusions in garnet and the garnet-pyroxene geothermometer, yielded temperatures of ${ }^{\prime} 540{ }^{\circ} \mathrm{C}$. The coexistence of Grt $+\mathrm{Rt}+\mathrm{Qtz}$ as it is indicated by numerous inclusions of rutile and quartz in garnet and the presence of clinozoisite and titanite as additional phases in the mineral assemblages, suggests that the minimum pressure was above 21 Kbar for a temperature of $540{ }^{\circ} \mathrm{C}$. An upper pressure limit is constrained by the stability of paragonite (Fig. 5), which is present as inclusions in garnet as well as in the matrix. Applying the garnet-phengite-omphacite geobarometer pressures of ' $25 \mathrm{Kbar}$ were derived. The P-T conditions obtained lie within the stability field of diaspore, present in the matabauxites, that occurs as lensoidal bodies within the marbles overlying the pre-Alpine basement in the north part of Ios.

Decompression was within the stability field of diaspore, since corundum has not formed in the metabauxites of Ios, indicating rapid uplift. Applying the garnet-hornblende geothermometer on coexistent garnet-hornblende and the garnet-chlorite geothermobarometer on coexistent garnet(rim)-chlorite(matrix) pair a temperature of $520{ }^{\circ} \mathrm{C}$ and P-T conditions of $15 \mathrm{Kbar}$ and $450{ }^{\circ} \mathrm{C}$ are derived, respectively, indicating that decompression was accompanied by a slow cooling at the first stages of uplift (Fig. 5).

\section{DISCUSSION - CONCLUSIONS}

Previous workers referred to an Hercynian metamorphic event (300 Ma) that took place under amphibolite facies conditions and affected both the garnet-mica schists and the metagranitic rocks (Henjes-Kunst \& Kreuzer, 1982; Van der Maar; 1981; Andriessen et al., 1987). The protolith of metagranitic rocks was considered to have intruded at $500 \mathrm{Ma}$ and Ios basement was thought to be similar to Menderes Massif (Papanikolaou \& Demirtasli, 1987).

However, no mineral assemblage has formed in metagranitic rocks, related to the Hercynian amphibolite facies metamorphism. Furthermore, the observed pre-Alpine assemblages in the metagranites have only magmatic textures. This is in agreement with the new $\mathrm{Pb}-\mathrm{Pb}$ isotopic data, on zircons, $(302 \pm 3$ to $311 \pm 2 \mathrm{Ma})$, interpreted as the ages of the granite intrusions (Engel \& Reischmann, 1998).

As it is deduced from the field observations and the mineral parageneses of the basement rocks in combination with the new radiochronological data the pre-Alpine evolution of Ios basement includes a high temperature metamorphic event leading to the regional migmatization of metapelitic rocks prior to granite intrusions. The residual migmatitic textures in the garnet-mica schists, the occurrence of muscovite pegmatites only within the garnet-mica schists and their lack in metagranitic rocks, as well as, the total lack of metamorphic zonation around the metagranitic rocks, indicate that the granitic melts intruded in rocks that had already suffered a HT metamorphism (M0). The Ca-poor almandine garnet and the Ti-rich biotite in garnet-mica schists formed during the pre-Alpine HT event. In metagranitic rocks Ti-rich biotite, pure muscovite and perthitic K-feldspar are of magmatic origin.

The Alpine HP metamorphism that affected the cycladic crystalline belt, is, also, well imprinted in Ios Island. It is recognized by the presence of index HP minerals both in the Mesozoic cover rocks as well as in the basement ones. K-Ar and Rb-Sr isotopic studies suggest Eocene ages for the HP-event (Henjes-Kunst \& Kreuzer, 1982; Andriessen et al. 1987). In basement rocks, it is recognized by the presence of blue amphibole, phengite, omphacite and garnet with higher grossular component than the pre-Alpine one. Geothermobarometry of coexistent mineral phases yielded P-T conditions of the peak HP-event ' $540{ }^{\circ} \mathrm{C}$ and ' $25 \mathrm{Kbar}$, indicating that during the HPevent the Ios basement was subducted at a depth ' $85 \mathrm{Km}$. The determined pressures in this work are at least 14 Kbar higher than those reported by Van der Maar (1981) and are the highest reported so far for the HP-event in Ios.

Exhumation of the HP metamorphic rocks was accomplished through the Southern Cyclades Shear Zone (Vandenberg \& Lister, 1996) and Ios Detachment Fault System that lasted till Miocene. The mylonitization 
along the Southern Cyclades Shear Zone took place during exhumation processes, as it is indicated by the lower phengitic content of the K-white mica rim in comparison with the respective one of the less deformed metagranite.

\section{REFERENCES}

ALTHERR R., KREUTZER H., WENDT J., LENZ H., WAGNER G.A., KELLER J., HARRE W., HOENDORF A. 1982. A late Oligocene/Early Miocene High Temperature Belt in the Attic-Cycladic Crystalline Complex SE Pelagonian, Greece. Geol. Jb., E23, 97-164, Hanover

ANDRIESSEN P.A.M., BANGA G. \& HEBEDA E.H. 1987. Isotopic age study of pre-Alpine rocks in the basal units on Naxos, Sikinos and Ios, Greek Cyclades. Geologie Mijnb. 66, 3-14

BERMAN, R.G. 1990. Mixing properties of Ca-Mg-Fe-Mn garnets, Am. Mineral., 75, 328-344

BERMAN R.G. 1991. Thermobarometry using multiequilibrium calculations: a new technique with petrologic applications. Canadian Mineralogist, 29, 833-855.

BROECKER M. \& ENDERS L. 1999. U-Pb zircon geochronology of unusual ecligite-facies rocks from Syros and Tinos (Cyclades, Greece). Geol. Mag., 136, 111-118

BUCHER, K. \& FREY, M. 1994. Petrogenesis of metamorphic rocks. Springer Verlag

DURR C., ALTHERR R., KELLER J., OKRUSCH M., SEIDEL E. 1978. The Median Aegean Crystalline Belt: Stratigraphy, Structure, Metamorphism, Magmatism. Alps, Apennines, Hellenides. Edited by H. Closs-D. RoederK. Schmidt, Int. Un. Com on Geod., Sc. Rep., 38, 455-477

ENGEL M. \& REISCMANN T. 1998. Single Zircon geochronology of orthogneisses from Paros, Greece, Bulletin of the Geol. Soc. Of Greece, x×xÉE, 3, 91-99

FERRY, J.M. \& SPEAR, F.S. 1978. Experimental calibration of the partitioning of Fe and $\mathrm{Mg}$ between biotite and garnet. Contrib. Mineral. Petrol, 66, 113-117

GRAHAM, C.M. \& POWELL, R. 1984. A garnet-hornblende geothermometer: calibration, testing and application to the Pelona Schist, Southern California, J. Metamorphic Geology, 2, 13-21

GRAMBLING J.A. 1990. internally-consistent geothermobarometry and $\mathrm{H}_{2} \mathrm{O}$ barometry in metamorphic rocks: the example garnet-chlorite-quartz. Contrib. Mineral. Petrol., 105, 617-628

HENJES-KUNST F. \& KREUZER H. 1982. Isotopic dating of pre-alpidic rocks from the island of Ios (Cyclades, Greece). Contrib. Mineral. Petrol., 80, 245-253

LANGOSCH, A., SEIDEL, E., STOSCH, H.G. \& OKRUSCH, M. 2000. Intrusive rocks in the ophiolitic melange of Crete - Witnesses to a Late Cretaceous thermal event of enigmatic geological Contrib. Mineral. Petrol., 139,339-355

MANNING, C. E. \& BOHLEN, S.R. 1991. The Reaction Titanite+Kyanite=Anorthite+Rutile and Titanite-Rutile Barometry in Eclogites, Contrib. Mineral. Petrol., 109, 1-9.

PAPANIKOLAOU D. 1996. The tectonostratigraphic terranes of the Hellenides. Ann. Geol. Payes Helleniques, 495-514

PAPANIKOLAOU D. \& DEMIRTASLI E. 1987. Geological correlations between the Alpine segments of the Hellenides-Balcanides and Taurides-Pontides. Mineralia Slovaka, Monography, 387-396

POWELL R. 1985. Regression diagnostics and robust regression in geothermometer/geobarometer calibration:the garnet-clinopyroxene geothermometer revisited, J. Metamorphic Geol., 2, 33-42

VANDENBERG L. \& LISTER G. 1996. Structural analysis of basement tectonites from the Aegean metamorphic core complex of Ios, Cyclades, Greece. J. Structural Geology, 18, 1437-1454

VAN DER MAAR P. 1981. Metamorphism on Ios and the geological history of the Southern Cyclades, Greece. Geologica Ultrajectiva, 28, 1-142

VIDAL, O., GOFFE, B., BOUSQUET, R. \& PARRA, T. 1999. Calibration and testing of an empirical chloritoidchlorite Mg-Fe exchange thermometer and thermodynamic data for daphnite, J. Metamorphic Geology, 17, 25-39

WATERS, D. \& MARTIN, H.N. 1993. The garnet-clinopyroxene-phengite barometer, Terra Abstr., 5, 410-411 